\title{
Joanna Szumańska
}

Instytut Sztuki PAN

Łazienki Królewskie w Warszawie

\section{WIZERUNKI RÓWNOLEGŁE STANISŁAWA AUGUSTA PODCZAS INAUGURACJI TEATRU KRÓLEWSKIEGO W STAREJ ORANŻERII 6 WRZEŚNIA 1788}

Gmach Starej Oranżerii, w którego sercu znajduje się Teatr Królewski, został wzniesiony w latach 1785-1788 w zachodniej części ogrodów Łazienek Królewskich. Była to jedna z największych inwestycji Stanisława Augusta, zaprojektowana przez nadwornego architekta Dominika Merliniego, który był również architektem Rzeczypospolitej. ${ }^{1}$ Obiekt zyskał kształt podkowy z elewacją podzieloną półkoliście zamkniętymi porte-fenêtre'ami. Od północy dostawiono dwa skrzydła; zachodnie przeznaczono na mieszkania i pomieszczenia pomocnicze, wschodnie - na teatr.

Budynek Starej Oranżerii kryje w sobie jeden z kilku zachowanych w Europie osiemnastowiecznych teatrów dworskich, jednak elewacja obiektu nie zdradza istnienia $\mathrm{w}$ jego wnętrzach sali widowiskowej. W zamyśle króla i artystów z nim współpracujących miał on zaskakiwać i otwierać na pragnienie zobaczenia czegoś nowego w sposób, w jaki do tej pory nie można było tego doświadczyć. ${ }^{2}$ Miał służyć również zaspokajaniu ambicji i gustów arystokracji, która brała udział w widowiskach, za każdym więc razem odbywające się w nim spektakle były sprawdzianem władzy.

Drewniany teatr ukończono na początku września 1788, jego inauguracji dokonano w dwóch etapach, 6 i 14 września tego roku. Obie uroczystości uświetniały rocznicę królewskiej elekcji. Podczas gdy pierwsze wydarzenie miało charakter théâtre de société, czyli teatru rozumianego jako rodzaj zabawy dla dystyngowanego towarzystwa, drugie było widowiskiem otwartym i, jak pisały ówczesne ga-

1 M. Pieczara, Włosi w Polsce Stanisława Augusta. Stownik obecności, Warszawa 2012, s. 175.

2 M. Murawska, Obnażyć sztukę. Fenomen dzieła sztuki w fenomenologii Jeana Luca Mariona i Henriego Maldineya, [w:] Fenomen i przedstawienie. Francuska estetyka fenomenologiczna. Założenia/zastosowania/konteksty, red. I. Lorenc, M. Salwa, P. Schollenberger, Warszawa 2012, s. 268-269. 
zety, „cała prawie Warszawa wyszła ku Łazienkom, przyległą Ujazdowską górę, dachy nawet i drzewa ludźmi obsypując". ${ }^{3}$ Poza walorami widowiskowymi oba wydarzenia miały również określone cele polityczne, wpisywały się w szeroki wątek społeczny i ideologiczny. Poprzez swoją wystawność i zdefiniowany program artystyczny ukazywały wartości dworu Stanisława Augusta, ich celem było również ustanawianie tożsamości króla. Stanisław August, podobnie jak inni monarchowie, potrzebował wsparcia iluzji teatralnych efektów, rekwizytów i gestów, aby uświetniać swoje panowanie organizacją obchodów rocznicowych, pulsujących monarszym przepychem. Łazienki służyły właśnie tego typu widowiskom.

O tym, że inauguracja, mająca miejsce 6 września, udała się doskonale i była harmonijną wizją artystyczną, świadczy relacja jednego z uczestników wydarzenia. L'abbé Renaud wspomina, że elita arystokratyczna bawiła się bardzo dobrze, w lot łapała aluzje i reagowała z wielkim entuzjazmem. Wystrój wnętrza przywodzić miał na myśl salę dla dystyngowanego towarzystwa, która była szczęśliwym zespoleniem smaku rzymskiego z francuskim, charakterystycznym dla czasów Ludwika XIV. ${ }^{4}$ Zgromadzona w Teatrze Królewskim publiczność miała okazję podziwiać dwie francuskie komedie w oryginale: La partie de chasse d'Henri IV Charles'a Collé i George Dandin Molière'a oraz polski balet Rybaki w choreografii Daniela Curza.

Otwarciu teatru dworskiego w 1788 sprzyjała sytuacja polityczna Rzeczypospolitej i ówczesne wsparcie dla rozwoju sztuk i nauk. Po pierwszym rozbiorze Polski nastąpił bowiem nowy etap w historii panowania Stanisława Augusta, związany z osobą Ottona Magnusa van Stackelberga. Ten nowo przybyły ambasador rosyjski w Warszawie (od września 1772) początkowo podjął współpracę z przeciwnikami politycznymi króla, skupionymi już dawniej wokół ambasady rosyjskiej. ${ }^{5}$ Jednak wydarzenia polityczne czasów sejmu rozbiorowego (1773-1775) i późniejsza sejmowa praca nad reformą ustrojową w 1776 sprawiły, że uznał króla za najbardziej przewidywalną siłę polityczną. Lata ,prokonsulatu Stackelberga" trwające do początku Sejmu Wielkiego były najspokojniejszym okresem rządów Stanisława Augusta. Służyły zarówno rozwojowi gospodarki okrojonego państwa, jak i edukacji obywateli, na którą polski monarcha kładł szczególny nacisk. Ważną rolę pełniła tu powołana w 1773 Komisja Edukacji Narodowej, będąca pierwszym w Europie ministerstwem oświaty. Dzięki jej sukcesowi Stanisław August jawił się jako „mądry król”, a na polu edukacyjnym jego autorytet był bezsporny. ${ }^{6} \mathrm{~W}$ latach osiemdziesiątych XVIII wieku rozwijał się również

Teatr Narodowy 1765-1794, red. J. Kott, Warszawa 1967, s. 584.

4 L. Bernacki, Teatr, dramat i muzyka za Stanistawa Augusta, Lwów 1925, t. I, s. 433.

5 D. Dukwicz, Kontakty Stanistawa Augusta z ambasadorami Katarzyny II w Warszawie w świetle „Pamiętników” królewskich, [w:] Pamiętniki Stanisława Augusta i ich bohaterowie, red. A. Grześkowiak-Krwawicz, Warszawa 2015, s. 284-285.

6 E. Rostworowski, Ostatni król Rzeczypospolitej. Geneza i upadek Konstytucji 3 maja, Warszawa 1966, s. 109; zob. też: W. Konopczyński, Dzieje Polski Nowożytnej, t. II, Warszawa 1986, s. 211-226; J. Michalski, Stanisław August, Warszawa 2009, s. 37-50 i 88-98; A. Zamoyski, Ostatni król Polski, Warszawa 1994, s. 207-225; M. Klimowicz, Oświecenie, Warszawa 2012, s.119-122. 
mecenat teatralny Stanisława Augusta. Począwszy od 1782, rosła intensywność życia teatralnego i muzycznego w Łazienkach, a jego największy rozkwit to lata $1788-1790 .^{7}$

Widowisko w Teatrze Królewskim powołane przez Stanisława Augusta 6 września 1788 było przedmiotem wielu studiów specjalistycznych z historii, historii teatru czy historii sztuki. Badacze analizowali zarówno wystrój Starej Oranżerii z Teatrem Królewskim, jak również wspomniane przedstawienia teatralne i balet. ${ }^{8}$ Poza obszarem zainteresowania naukowców pozostały jednak kwestie ukazania wizerunków równoległych króla i intercielesności monarchy, dającej się zauważyć w tym widowisku. Niniejszy szkic stanowi próbę wypełnienia tej luki poprzez spojrzenie na wizerunki monarchy całościowo. Jego głównym zadaniem jest zbadanie portretów Stanisława Augusta, zarówno dekorujących salę teatralną, jak również bardziej ulotnych -,,wizerunków” metaforycznych, ewokowanych przez sztuki teatralne i balet. Przedmiotem rozważań będzie sposób, w jaki sztuki wizualne, dzieła dramatyczne i balet łączono ze sobą, aby oświetlały się nawzajem, tworząc opowieść o królu oraz krążenie między ciałem własnym monarchy a jego ciałami wyobrażonymi, tzw. ruch intercielesności. ${ }^{9}$

Badacz, mający za zadanie stworzenie opisu widowiska teatralnego, napotyka na szereg trudności, ponieważ istotą teatru jest ulotność - ,analogiczna do ulotności życia ludzkiego. A jego transcendentne trwanie to proces, który można ukazać i którego można doświadczać w czasie trwania widowiska. Nie dłużej”. ${ }^{10}$ W przypadku widowiska inaugurującego otwarcie Teatru Królewskiego kwestia ta jest nieco ułatwiona, bo do dzisiaj zachowało się oryginalne osiemnastowieczne wnętrze, dzięki czemu „nadal [możemy próbować odtworzyć to wydarzenie] z pewnego punktu naszego trwania. Miniony czas zostaje więc niejako zachowany i uchwycony w teraźniejszości". ${ }^{11}$

Wnętrze Teatru Królewskiego imponuje bogatym wystrojem malarskim i rzeźbiarskim. Widownia została założona na planie kwadratu z amfiteatralnie ustawionymi ławkami. Na wprost sceny umieszczono centralną lożę królewską oraz loże boczne, zaprojektowane z myślą o rodzinie króla. ${ }^{12} \mathrm{~W}$ górnej kondygnacji znajduje się w sumie dziewięć lóż - po trzy na każdej ścianie - podzielonych parami

A. Żórawska-Witkowska, Muzyka na dworze i w teatrze Stanistawa Augusta, Warszawa 1995, s. 28.

8 Zob. B. Król-Kaczorowska, Lazienkowski Teatr w Pomarańczarni, Warszawa 1961 oraz opracowania m.in. Z. Raszewskiego, A. Rottermunda, A. Żórawskiej-Witkowskiej, P. Kenckiego, D. Juszczak i H. Małachowicz.

9 Maurice Merleau-Ponty porównuje ciało ludzkie do dzieła sztuki. M. Merleau-Ponty, Fenomenologia percepcji, przekł. M. Kowalska, J. Migasiński, Warszawa 2001, s. 324.

10 K. Braun, Pomiędzy teatrem a sztukami pięknymi, [w:] Arx felicitatis. Księga ku czci Profesora Andrzeja Rottermunda w sześćdziesiąta rocznicę urodzin od przyjaciól, kolegów $i$ wspótpracowników, red. J. A. Chrościcki, J. Guze, P. Mrozowski, S. Mossakowski, J. K. Ostrowski, M. Poprzęcka, W. M. Rudzińska, M. Sołtysiak, J. Ziembiński, Warszawa 2001, s. 676.

11 M. Merleau-Ponty, Widzialne i niewidzialne, przekł. M. Kowalska, Warszawa 1996, s. 87.

12 B. Król-Kaczorowska, Budynek teatru, Wrocław 1975, s. 95. 


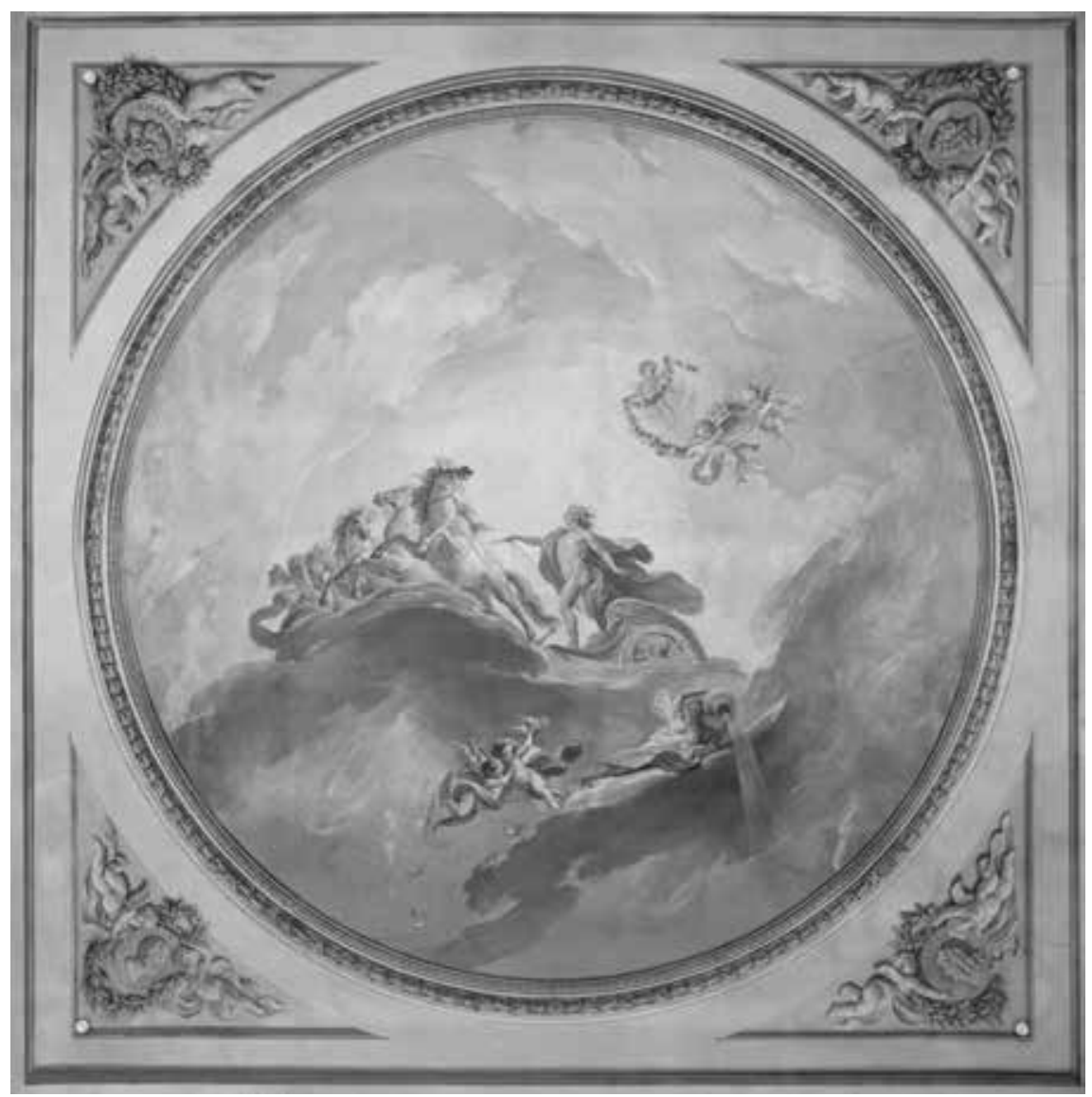

Jan Bogumił Plersch, Plafon w Teatrze Królewskim w Starej Oranżerii, 1788, Muzeum Łazienki Królewskie. Fot. K. Stasiuk

przyściennych korynckich pilastrów. Pomiędzy nimi ustawiono osiem posągów kobiet $\mathrm{w}$ antykizujących szatach, wykonanych w narzucie. Figury różną się nieznacznie w szczegółach, każda z nich trzyma dwa sześcioramienne świeczniki, wykonane ze złoconego drewna. ${ }^{13}$ Rzeźby te są dziełem André Le Bruna i Jakuba Monaldiego, a dekoracje stiukowe wykonał Piotr Staggi.

Widownię otaczają malowidła wykonane w technice al fresco - dzieło Jana Bogumiła Plerscha ${ }^{14}$ - mające charakter ściśle hierarchiczny. Sferę boską stanowi plafon, a sferę dworską namalowana iluzjonistycznie osiemnastowieczna publiczność

13 Ibidem.

14 Aleksandra Bernatowicz wymienia osiemnastowieczne publikacje, które pomagały Plerschowi w wykonywaniu malowideł plafonowych, wykreślaniu iluzjonistycznej architektury, projektowaniu pejzaży scenografii teatralnej i operowej, zob. A. Bernatowicz, Malarze w Warszawie czasów Stanisława Augusta. Status - Aspiracje - Twórczość, Warszawa 2016, s. 262. 
w lożach. Plafon, stanowiący zwornik dla całego wnętrza, skomponowano na planie koła wpisanego w kwadrat. W jego centrum znajduje się Apollo na kwadrydze, pod postacią którego Plersch przedstawił Stanisława Augusta. Bóg otoczony jest przez putta, trzymające girlandy z kwiatami. Poniżej kwadrygi, na ciemnej chmurze ukazano Eos wylewającą wodę z dzbana, a w rogach plafonu postaci czterech dramatopisarzy, których najwyżej cenił Stanisław August: Sofoklesa, Shakespeare'a, Molière'a i Racine'a. ${ }^{15}$

Apollo został uchwycony w chwili, gdy wjeżdża na kwadrydze na nieboskłon. Malarz przedstawił go wśród chmur, odwołując się do Homera, u którego bogowie zawsze pojawiają się na obłokach. ${ }^{16}$ Postać monarchy przedstawiono na wzór boga greckiego, a twarz wyobrażono z troską o zachowanie podobieństwa do polskiego króla, aby nie było wątpliwości, że Apollo to sam Stanisław August. Złocista kolorystyka portretu króla przyciąga uwagę i podkreśla jego godność. Został on przez artystę tak uchwycony, aby wywoływać wrażenie zatrzymania się tylko na chwilę, by za moment opuścić pole obrazu, uchodząc naszym spojrzeniom. Twarz monarchy zwrócona jest w lewą stronę, król odwraca od nas głowę, jego pełne napięcia spojrzenie kieruje się w punkt dla nas niewidoczny. Miejsce, które przed nim się otwiera, jest dla nas niedostępne, nie zostało ukazane w obszarze malowidła.

Plafon w Starej Oranżerii ukazuje ,nieśmiertelne ciało króla tożsame z jego maską i rolą, jaką przywdziewa jego śmiertelna powłoka [...]. Fikcyjne ciało ukazuje jego właściwą, wyabstrahowaną rolę. Ma przesłaniać, czy raczej wytłumić, jego naturalne ciało". ${ }^{17}$ Monarcha, prezentując się w ten sposób, odwołuje się do epoki francuskich Ludwików ${ }^{18}$, którzy przedstawiali siebie jako Apollina - mecenasa sztuk i opiekuna muz. W przestrzeni Teatru Królewskiego wizerunek boga greckiego z twarzą monarchy jest słuszny i szlachetny, ponieważ teatr ten był pomyślany jako miejsce harmonii sztuk, a Apollo miał, zgodnie ze swym

15 P. Kencki, Czterej dramatopisarze w Teatrze Królewskim w Starej Oranżerii, lazienki-krolewskie.pl/pl/edukacja/baza-wiedzy/czterej-dramatopisarze-w-teatrze-krolewskim-w-starej-oranzer.

${ }_{16}$ Voltaire, Stownik filozoficzny, przekł. M. Skrzypek, Warszawa 2015, s. 143: „Opary wychodzące z mórz i ziemi, które tworzą chmury, zjawiska meteorologiczne i grzmoty, brano początkowo za siedzibę bogów. U Homera bogowie schodzą zawsze na złotych chmurach; dlatego jeszcze dzisiaj malarze przedstawiają ich jako siedzących na chmurze".

17 M. Zabdyr-Jamróz, Czy doktryna Dwóch Ciat Króla jest zaprzeczeniem demokracji? Dwa Ciała Króla w karnawale demokracji, „Politeja” 2016, nr 45, s. 69.

${ }_{18}$ Na temat wizerunków Ludwika XIV jako Apollina zob. P. Burke, Fabrykacja Ludwika XIV, przekł. M. Szczubiałka, R. Pucek, Warszawa 2011, szczególnie s. 40-42. Przykładami takiego przedstawienia są m.in. wizerunki francuskiego monarchy w przebraniu Apollina i inskrypcja w Musée Carnavalet, Histoire de Paris:

„And what the Sun admires,

Rome in one palace, in Paris an Empire,

And all the Caesars in one King",

parismuseescollections.paris.fr/fr/musee-carnavalet/oeuvres/monde-vient-voir-ce-que-ie-vois-etce-que-le-soleil-admire-rome-dasn-un\#infos-principales,

en.chateauversailles.fr/discover/history/louis-xiv\#king-by-divine-right. 
rodowodem, roztaczać blask i panować również nad pięknym pozorem w wewnętrznym świecie fantazji. ${ }^{19}$

Obraz monarchy jako Apollina na teatralnym plafonie należało odczytywać alegorycznie i rozumieć jego odniesienia do teraźniejszości. Ciało boga greckiego miało uosabiać koncepcje oświeceniowe, które wprowadzał Stanisław August w Rzeczypospolitej. Analizując ten wizerunek warto jeszcze zwrócić uwagę na fragment Pamiętników, w których Stanisław August tak rysuje swój portret:

Naczytawszy się rozmaitych portretów, ochoty nabrałem, aby swój nakreślić. Zadowolony byłbym postaci swojej, gdybym tylko był o jeden cal wyższy, nogi miał kształtniejsze, nos mniej orli, biodra węższe, wzrok bystrzejszy i zęby bardziej wydatne. Nie znaczy to, abym po wszystkich tych poprawkach uznał, iż nader jestem piękny, ale nie pragnę wcale piękniejszym być, znajduję bowiem, że fizjonomię mam szlachetną i wielce wyrazistą, a w ruchach i całej mej postawie na tyle mi dystynkcji dostaje, bym uwagę zwracał. ${ }^{20}$

Dalej Stanisław August podkreśla, że najwierniej oddaje jego ciało Portret w stroju koronacyjnym pędzla Bacciarellego, znajdujący się w Sali Marmurowej na zamku warszawskim. ${ }^{21}$

Poniżej teatralnego plafonu z figurą Apollina, w sferze dworskiej ukazano iluzjonistycznie w rzędach dziewięciu lóż arystokratyczną publiczność i jest to jedyne zachowane malowidło przedstawiające spektatorów z tamtych czasów. Możemy dostrzec zarówno postaci Sarmatów, jak i tych ubranych z francuska. Każdy wygląda odpowiednio i ze smakiem, a przede wszystkim bogato, ponieważ dwór musiał błyszczeć i roztaczać blask przepychu. ${ }^{22}$ Twarze namalowanych arystokratów zwrócone są głównie na scenę teatru dworskiego i w stronę loży przeznaczonej dla monarchy.

Podczas inauguracji interesujący wydaje się zabieg zjednoczenia dwóch widowni - iluzjonistycznej i rzeczywistej. Uzyskano przez to „możliwość nie tylko spojrzenia na siebie $\mathrm{z}$ dystansu, lecz także przestrzennego usytuowania się wobec rzeczy $[\ldots]$ z otoczenia i innych ludzi; możliwość obiektywizacji [...] własnej, również kulturowej pozycji na świecie". ${ }^{23}$ Arystokracja mogła przeglądać się w iluzjonistycznych lożach namalowanych przez Plerscha i przyglądać się sobie nawzajem, ponieważ nie istniało rozgraniczenie między ,aktorami” i „publicznością”. Zniesiono granicę między światem alegorycznym a realnym. ${ }^{24}$

19 F. Nietzsche, Narodziny tragedii, wstęp i przekł. G. Sowiński, Kraków 2011, s. 89.

20 Pamiętniki króla Stanisława Augusta, przekł. W. Brzozowski, wstęp A. GrześkowiakKrwawicz, red. M. Dębowski, wybór tekstu D. Triaire, Warszawa 2013, s. 190.

21 Ibidem, s. 191.

22 W. S. Magdziarz, Uwodziciele władzy. Geneza i organizacja dworu Ludwika XIV, Warszawa 2013, s. 68-69.

${ }_{23}$ I. Lorenc, Minima aesthetica. Szkice o estetyce później nowoczesności, Warszawa 2010, s. 89.

24 E. Olechnowicz, Maski Karola I. Angielskie widowiska dworskie i teologia polityczna, Warszawa 2014, s. 55. 


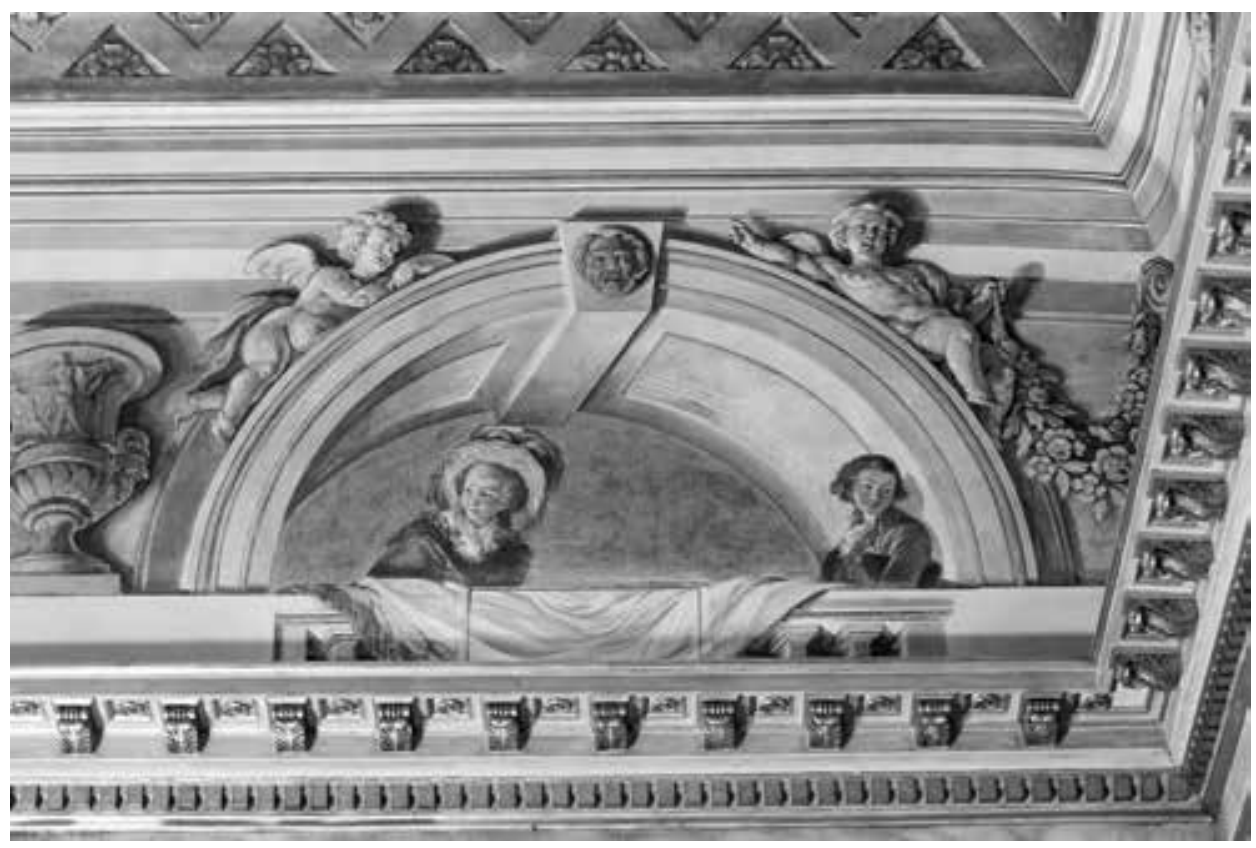

Jan Bogumił Plersch, Iluzjonistyczna loża w Teatrze Królewskim w Starej Oranżerii, 1788, Muzeum Łazienki Królewskie. Fot. K. Stasiuk

Porządek hierarchii dworskiej oraz porządek mitologicznego świata w Teatrze Królewskim przekazywały informację, że nakreślony obraz dworu Stanisława Augusta jest idealnie zaplanowany i wszystko ma w nim swoje miejsce. Była to utopia, w której wyobrażone sztuczne ciała nigdy nie umierają. Ciała te, będąc fikcjami, przybierają pozór realności. „Ale fikcje te niekoniecznie są fałszem. A nawet jeśli są, to potrafią być słuszne i - odwracając tezę autora Woli mocy «do wielu rzeczy całkiem przydatne»»". ${ }^{25}$

Namalowane iluzjonistycznie ciała spektatorów i ciało króla jako Apollina zdają się być ukazane w tej samej przestrzeni, którą sugeruje błękitne tło przywodzące na myśl sferę niebieską. Twarze spektatorów są pogodne i widać na nich zainteresowane widowiskiem. Uderzający jest brak tzw. wojny fraka z kontuszem oraz starcia idei oświeceniowych $\mathrm{z}$ antyoświeceniowymi. Zatrzymane $\mathrm{w}$ ruchu pozy symbolizują afirmację społecznie zorganizowanego pozoru. Eleganckie towarzystwo robi to, na co ma ochotę. Niektórzy prowadzą rozmowy, plotkują, inni obserwują scenę, jeszcze inni spoglądają w stronę miejsca przeznaczonego dla monarchy. Loże zdają się być idealnie wyreżyserowane, możemy podziwiać w nich grę między spektatorami wykreowaną na kształt widowiska.

25 M. Zabdyr-Jamróz, op. cit., s. 70. Michał Zabdyr-Jamróz przywołuje i cytuje Nietzchego; F. Nietzche, Wola mocy jako poznanie, [w:] idem, Wola mocy, przekł. S. Frycz, K. Drzewiecki, Warszawa 1911. 


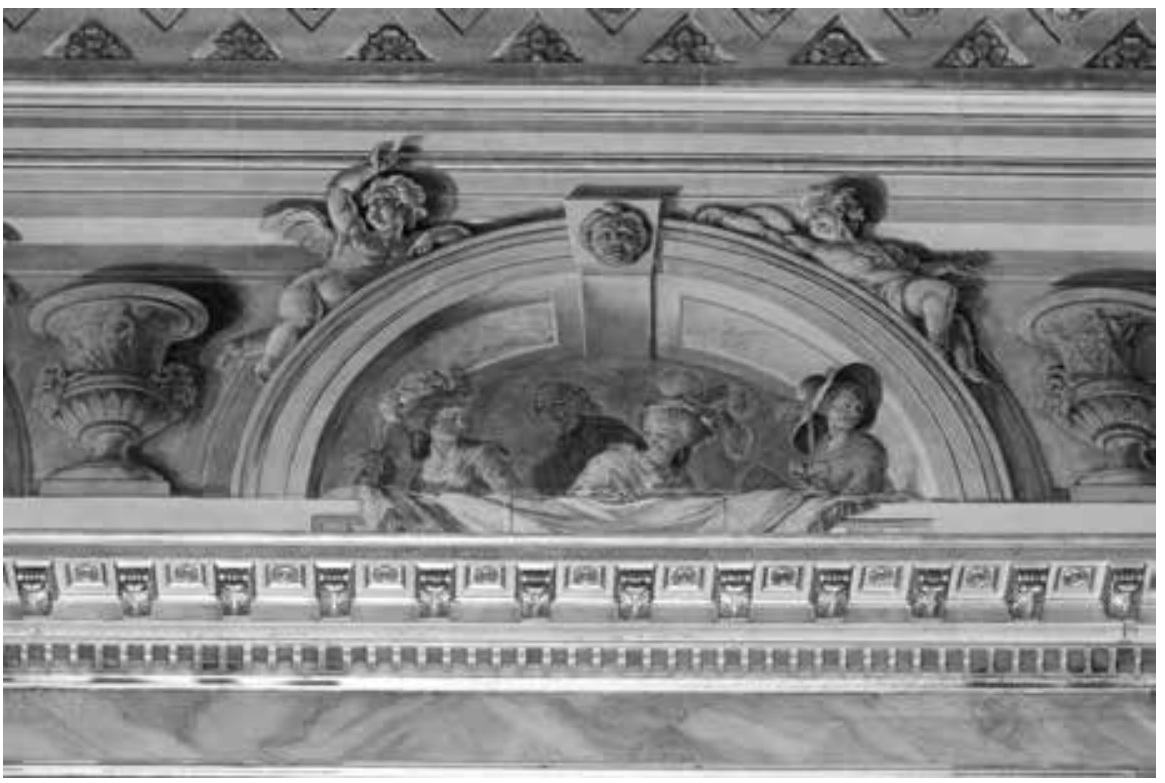

Jan Bogumił Plersch, Iluzjonistyczna loża w Teatrze Królewskim w Starej Oranżerii, 1788, Muzeum Łazienki Królewskie. Fot. K. Stasiuk

Malowidło plafonowe przyciąga również uwagę wizerunkami czterech dramatopisarzy ukazanych profilowo w medalionach, którzy znajdują się w tej samej przestrzeni, co monarcha. Wybór rygorystyczny, tylko czterej w całym teatrze. Ci sami - już wśród grona innych - znaleźli się na attyce Amfiteatru w Łazienkach, otwartego trzy lata później. Zastanawiające jest, dlaczego właśnie tych wybrał Stanisław August, jak ich portrety współuczestniczyły w tworzeniu kulturowej chwili ${ }^{26} \mathrm{i}$ jak różnorodne reprezentacje władzy w ich dramatach pomagały królowi w budowaniu własnej tożsamości.

\section{SOFOKLES}

Najstarszy z przedstawionych dramatopisarzy to Sofokles, który „,założył pierwsze znane nam w dziejach stowarzyszenie intelektualistów - wielbicieli Muz". ${ }^{27} \mathrm{Z}$ siedemdziesięciu tragedii i osiemnastu dramatów satyrowych, które napisał, zachowało się siedem tragedii i jeden dramat. ${ }^{28}$ Jego dzieł nie wystawiano

26 S. Greenblatt, Poetyka kulturowa. Pisma wybrane, wstęp i przekł. K. Kujawińska-Courtney, Kraków 2006, s. IX.

27 J. Hernik Spalińska, Sofokles $i$ antyczny teatr grecki, wirtualne Muzeum Łazienek Królewskich, lazienki-krolewskie.pl/pl/edukacja/baza-wiedzy/sofokles-i-antyczny-teatr-grecki.

28 Ibidem. 
na deskach teatrów w osiemnastowiecznej Rzeczypospolitej, był on jednak niezwykle ceniony przez polskich myślicieli oświeceniowych i wymieniany wśród najwybitniejszych autorów greckich. ${ }^{29}$

W Katalogu Biblioteki Stanisława Augusta, sporządzonym przez Jana Chrzciciela Albertrandiego, w dziale Classici Graeci ${ }^{30}$ widnieją wszystkie tragedie dramatopisarza, a literatura antyczna i książki z zakresu teologii stanowią działy pod względem liczebności największe. Oprócz literatury antycznej monarcha gromadził również pozycje dostarczające wiedzy o starożytnościach. ${ }^{31}$

Sofoklesem interesowano się w całej Europie, zasadnicze znaczenie miała tu tradycja arystotelesowska. W Poetyce filozof ukazał ateńskiego dramatopisarza jako najdoskonalszego, a jego fabułę jako wzorcową do naśladowania, a ponieważ Poetyka była podstawą praktycznie wszystkich dyskusji na temat tragedii od XVI wieku, to wywarła olbrzymi wpływ na zachodnią dramaturgię i teorię krytyczną. Za sprawą Arystotelesa dramaty Ateńczyka stały się bardzo popularne i powstało wiele ich oświeceniowych wersji. W połowie XVIII stulecia Poetyka zainteresował się Gotthold Ephraim Lessing, który na nowo zinterpretował wytyczne Arystotelesa dotyczące dramatu i katharsis. ${ }^{32}$

Najsłynniejsze dramaty Sofoklesa to tzw. cykl tebański, składający się z trzech tragedii: Króla Edypa, Edypa w Kolonie i Antygony. Pisał je pod wpływem ówczesnej sytuacji politycznej. Wyraził w nich swoje poglądy prodelfickie i antyateńskie oraz przerażenie ateńskim oświeceniem ${ }^{33}$, akcentował również związek między ujawnieniem prawdy a sztuką rządzenia.

Temat Króla Edypa jako osnowę dla swoich tragedii wykorzystali Pierre Corneille i Voltaire. Filozof użył Sofoklesowego bohatera jako thumacza swoich antyreligijnych przekonań. Wprowadził do fabuły kiełkujące idee oświeceniowe i aluzje do sporu jezuitów z jansenistami. ${ }^{34}$ Jego Edyp nie czuje się winny i o barbarzyństwo oskarża bogów. Edyp Voltaire'a stał się tak popularny we Francji, że pozostawał w repertuarze Comédie-Française od premiery w dniu 18 listopada 1718 do 1852. Arystotelesowska tradycja ewoluowała w XVIII stuleciu, a ,imitacje" Edypa pióra Corneille’a i Voltaire’a były bardzo popularne. Zmieniały się dyskursy o społeczeństwie: dyskursy polityki, filozofii czy krytyki literackiej, ale Król Edyp Sofoklesa - uznana tragedia cieszyła się wciąż obfitością tłumaczeń na przełomie XVII i XVIII wieku. ${ }^{35}$

29 P. Kencki, Czterej dramatopisarze w Teatrze Królewskim w Starej Oranżerii, op. cit. s. 2.

30 Katalog Biblioteki Króla Stanisława Augusta sporządzony przez Jana Chrzciciela Albertrandiego, Poetae graeci, Biblioteka Narodowa, tom 5, nr 120.

31 A. Dzięcioł, Stanisław August Poniatowski i jego księgozbiór w świetle źródeł zachowanych w Bibliotece Narodowej Ukrainy w Kijowie, „Kronika Zamkowa” 2006 t. 1-2, s. 110-111.

32 E. Vodoklys, Sophocles in the Age of Goethe: An Analysis of Sophoclean Influence in the Klassik-Romantik Era, 1972. Fenwick Scholar Program 7; crossworks.holycross.edu/fenwick scholar/7.

33 J. Hernik Spalińska, op. cit.

34 M. Dębowski, Kłopoty Molière'a w XVIII wieku, „Pamiętnik Teatralny” 2014 z. 4, s. 150.

35 E. Nikolarea, Oedipus the King: A Greek Tragedy, Philisophy, Politics and Philology, s. 220. 
Sofoklesa niezwykle cenił również Denis Diderot. W dziele $O$ poezji dramatycznej tak wyraził się o ateńskim dramatopisarzu:

prosta intryga, akcja ujęta jak najbliżej końca, aby wszystko było doprowadzone do ostateczności; katastrofa bezustannie grożąca i zawsze oddalana dzięki prostym i prawdziwym okolicznościom, energiczne słowa, silne namiętności, obrazy, jeden lub dwa charaktery mocno zarysowane [...]. Sofoklesowi nie trzeba było więcej, aby wyprowadzić umysły $\mathrm{z}$ równowagi. ${ }^{36}$

Historia Edypa sytuuje go wśród najtragiczniejszych bohaterów. Jego los jest pełen stężenia zła i okropności oraz niezawinionego i nieuniknionego nieszczęścia. ${ }^{37}$ Władca, który próbuje wyjaśnić przyczynę zarazy w jego kraju, doprowadzającą do kryzysu państwowego, sam siebie skazuje na klęskę. Za kryzysem politycznym idzie kolejny - kulturalny. Pojawienie się w Atenach sofistów - nauczycieli mądrości, którzy uważali wierzenia religijne i moralność za coś umownego, spowodowało podważenie dawnej tradycyjnej religii. Sofokles pokazuje w swoich dramatach protest przeciwko upadkowi autorytetu Apollina w Atenach i opowiada się za Delfami z sympatiami monarchistycznymi, a przeciwko demokratycznym Atenom. ${ }^{38}$

Oświecenie zastąpiło sofistów encyklopedystami. Wtedy, jak pisał w 1773 Élie Fréron, „wytworzyła się pośród nas, jak dobrze o tym wiecie, konfederacja tak zwanych filozofów i dowcipnisiów, samych przez się bardzo słabych, których jednak łącząca ich więź uczyniła potęgą". ${ }^{39}$

„Wielka encyklopedia francuska”, której siłą miało być obiektywne przedstawienie rozwoju sztuk i nauk, stała się wywrotową i racjonalistyczną ideologią. Denis Diderot do jednego z wydawców Encyklopedii pisał:

Zapomniał pan, że pierwszych sukcesów nie przyniosły panu artykuły dorzeczne, rozsądne i pospolite, że nie ma chyba dwóch ludzi z towarzystwa, którzy by zadali sobie trud przeczytania jednej linijki historii, geografii, matematyki, a nawet sztuki, i że szukano tam i będą szukać odważnej i zuchwałej filozofii niektórych z pańskich współpracowników. Została ona przez pana skastrowana, poćwiartowana, okaleczona, rozdarta w strzępy bez zastanowienia się, bez miary i bez smaku. Zrobiłeś z nas ludzi miernych i płaskich. Usunąłeś ze swojej książki to, co było w niej i co mogło być jej atrakcyjnością, jej ostrzem, jej żywością i nowością. ${ }^{40}$

Filozofia oświeceniowa zwróciła się przeciwko tradycji religijnej, społecznej i etycznej, doszła do tego ,świadomość przemijalności świata, jego dekadencji

36 D. Diderot, Pisma estetycznoteatralne, przekł. M. Dębowski, J. Kott, E. Rzadkowska, A. Siemek, wstęp i oprac. M. Dębowski, Gdańsk 2008, s. 138.

37 A. Libera, Wstęp, [w:] Sofokles, Trylogia Tebańska. Król Edyp, Edyp w Kolonos, Antygona, spolszczył i oprac. A. Libera, Warszawa 2014, s. 17-18.

38 J. Hernik Spalińska, Anty-Ifigenia, Warszawa 2014, s. 39-42.

39 Cyt. za: B. Baczko, Wstęp, [w:] Filozofia francuskiego oświecenia, wybór, przekł. i oprac. B. Baczko, Warszawa 1961, s. 9-10.

40 Cyt. za: Jan Kott, Wstęp, [w:] Encyklopedia albo stownik rozumowany nauk, sztuk i rzemiost, przekł. E. Rzadkowska, Wrocław 1952, s. XI. 
i rozpadu. [...] i coraz silniejsze poczucie deziluzji i demaskacji”. ${ }^{41}$ Wtedy też „Zadano pierwszy - w zamierzeniu śmiertelny - cios Bogu, potem królowi (uosobionemu przez króla francuskiego), wreszcie ojcu". ${ }^{42}$

Sofoklesowy król Edyp, który na zagadkę Sfinksa odpowiedział: „To człowiek", stał się stereotypowym komunikatem oświecenia. ${ }^{43}$ Jak pisze Erich Fromm:

Jeśli przekładamy słowa Sfinksa z języka symbolicznego na język codziennego doświadczenia, słyszymy, jak mówi: zbawić ludzkość może tylko ten, kto wie, iż najważniejszą odpowiedzią, jakiej człowiek może udzielić na najtrudniejsze pytanie, przed którym go stawiam, jest sam człowiek. ${ }^{44}$

Wiek Świateł, który uwierzył w człowieka, w jego rozum i skłonność do dobra, boleśnie się rozczarował co do natury ludzkiej.

Sytuacja społeczno-polityczna Aten w dramatach Sofoklesa i rola sofistów, w którą w oświeceniu weszli encyklopedyści, pozwala dzisiaj zaproponować analogie między tragicznym losem Edypa a losami Stanisława Augusta i Ludwika XVI. Król Rzeczypospolitej Obojga Narodów i Król Francji wymieniani są bowiem wśród najtragiczniejszych postaci XVIII wieku. Stanisław August, kiedy wstąpił na polski tron w 1764, kierował jednym z największych krajów europejskich, a kiedy umierał w 1798, ów kraj już nie istniał. Świadomy kryzysu społeczno-politycznego, zwracał się często do Opatrzności. ${ }^{45}$ Zmarł na apopleksję w Pałacu Marmurowym w Petersburgu, gdzie przebywał na rozkaz cara po abdykacji. Ludwik XVI, władca jednej z najpotężniejszych monarchii absolutnych, utracił władzę i dokonał żywota na gilotynie. ${ }^{46}$

Za panowania tych władców, uwolnienie od złych uczuć i przeżyć, zgodnie $\mathrm{z}$ arystotelesowską katharsis, było szczególnie pożądane. Epoka oświecenia łaknęła takiego oczyszczenia. I oświecenie, jak każda epoka, aby mówić o problemach przybierało maski antyczne, ,szukając w starożytności wielkich wzorców i precedensów". 47

Wybór Stanisława Augusta, aby na teatralnym plafonie starożytnych reprezentował Sofokles, wydaje się oczywisty. Sofokles i antyczny teatr grecki to podstawy, na których konstytuowała się tożsamość osiemnastowiecznego teatru, ale już u progu nowożytności, od XV i XVI wieku obserwowano powrót do źródeł

${ }^{41}$ J. Kilian, Najjaśniejsza Republika... masek. Teatralizacja życia $w$ Wenecji $w$ dobie Oświecenia, [w:] Oświeceniowa republika władców. Rezydencje, kolekcje, mecenat, t. II, red. A. Pieńkos, Warszawa 2017, s. 198.

42 J. Hernik Spalińska, Anty-Ifigenia, op. cit., s. 51.

43 M. Horkheimer, T. W. Adorno, Dialektyka oświecenia, przekł. M. Łukasiewicz. M. J. Siemek, Warszawa 2010, s. 66.

44 E. Fromm, Zapomniany język. Wstęp do zrozumienia snów, baśni i mitów, przekł. K. T. Toeplitz, Warszawa 1951; cyt. za: J. Hernik Spalińska, Anty-Ifigenia, op. cit., s. 45.

45 J. Axer, Tropem lacińskich inskrypcji Stanisława Augusta, [w:] Eazienki Królewskie. Nowe świadectwa - nowe znaczenia, red. M. Poprzęcka, Warszawa 2013, s. 27-33.

46 A. Grześkowiak-Krwawicz, Stanisław August (1732-1798), lazienki-krolewskie.pl/pl/edukacja/baza-wiedzy/stanislaw-august-1732-1798.

$47 \quad$ M. Milewska, Ocet $i$ łzy, Gdańsk 2001, s. 202. 
starożytnych. Król - inicjator sceny narodowej, podobnie jak Arystoteles, najwyżej cenił tragedie, a obecność dzieł Sofoklesa w jego księgozbiorze mogła, za Arystotelesem, wyrażać przekonanie ,iż tragedia czytana osiąga równą żywotność oddziaływania jak wystawiana". ${ }^{48}$

\section{SHAKESPEARE}

Drugim dramatopisarzem widniejącym na plafonie jest Shakespeare, którego nazwisko umieszczono w medalionie w pisowni oryginalnej. ${ }^{49}$ Stanisław August interesował się twórczością mistrza ze Stratfordu i niezwykle go cenił. Jego dzieła poznał podczas swojej młodzieńczej podróży po Europie. Pod koniec 1754 w Londynie dwudziestoletni Poniatowski w towarzystwie lorda Strange'a, dziedzica hrabstwa Derby, oglądał przedstawienia szekspirowskie. Swoje wrażenia utrwalił w Pamiętnikach napisanych w 1772:

Tenże lord Strange pierwszy zabrał mnie na tragedię Szekspira. Wybrałem się na przedstawienie, w pamięci mając piękną zasadę trzech jedności, których przestrzeganie sprawia, iż poeci francuscy za wyższych mają od Anglików. Ale wyznam, że im więcej Szekspira sztuk widziałem, tym bardziej w tym względzie poczułem się heretykiem. Bardzom był nimi przejęty, szczerze ubawiony, a często i naukę wyciągnąłem, uznałem przeto, że wynieść mogę przyjemność i pożytek także ze sztuk, które ponad dzień jeden trwają i w różnych się rozgrywają miejscach - jeżeli tylko autor dobrze zna obyczaje, namiętności i dziwactwa ludzkie, a także i piękne uczynki, do jakich człowiek jest zdolny, oraz sprawić umie, iż aktorzy przemawiają tak, że w moich oczach rośnie wartość cnoty, dobroci i mądrości, a wszystko to przedstawione jest nader wiarygodnie. Owóż sądzę, że szczegóły, w które angielskie sztuki, a zwłaszcza Szekspira, tak obfitują, i które tak dobrze oddają złudzenie czasów i krajów, gdzie rzecz się dzieje, dalece bardziej są przekonujące niźli potrójna jedność wyniosłych zawsze i napuszczonym stylem pisanych tragedii francuskich - a bez złudzenia nie masz wcale przyjemności w teatrze. Ale przyjemność mówienia o Szekspirze zbyt daleko mnie zaprowadziła, wracam tedy do mojej podróży ${ }^{50}$

Z tych wspomnień niestety nie dowiadujemy się, jakie przedstawienia widział przyszły władca. Jednak dzięki repertuarowi teatrów Covent Garden i Drury Lane z drugiej połowy XVIII wieku wiemy, co miał wówczas do wyboru. Na afiszu podczas jego pobytu były najwybitniejsze dzieła Shakespeare'a, m.in. Juliusz Cezar, Ryszard III, Kupiec wenecki, Makbet czy Hamlet. W uznanych arcydziełach grali wybitni aktorzy, Poniatowski mógł podziwiać m.in. Davida Garricka, Sprangera Barry'ego, Anne Bellamy. ${ }^{51}$ Podczas młodzieńczej podróży odwiedził

48 B. Judkowiak, Przyjemność w teoriach dramatyczno-teatralnych i jej osiemnastowieczne rewizje, [w:] Przyjemność w kulturze epoki rozumu, red. T. Kostkiewiczowa, Warszawa 2011, s. 229-231.

49 Zob. J. Komorowski, ,, Wymawia się Szekspir”. Mistrzowi Williamowi w czterechsetna zgonu jego rocznice, ,Pamiętnik Teatralny” 2016 z. 3.

50 Pamiętniki króla Stanisława Augusta, op. cit., s. 138-139.

51 J. Komorowski, Nie tylko Shakespeare. Studia z dziejów teatru i dramatu XVI-XX wieku, Warszawa 2011, s. 21-22. 
również angielską prowincję, Bath, Oxford, Stonehenge oraz ogród księcia Buckingham w Stowe. Być może w Stowe widział Świątynię Brytyjskich Znakomitości, w której pośród innych umieszczono popiersie Shakespeare'a i Alexandra Pope'a. ${ }^{52}$ Tych właśnie pisarzy niezwykle cenił, a ich dzieła znajdowały się w jego księgozbiorze. ${ }^{53}$

Świadectwem szekspirowskiej fascynacji Stanisława Poniatowskiego jest również próba tłumaczenia z języka angielskiego na francuski I aktu Juliusza Cezara. W roku 1754 przełożył 265 wersów, czyli prawie jedną trzecią aktu I. Zapewne podstawą było londyńskie wydanie Alexandra Pope'a i Williama Warburtona z 1747. Możliwe, że pracę nad przekładem poprzedziły doświadczenia teatralne - Poniatowski mógł oglądać Juliusza Cezara 9, 12 lub 16 marca 1754 w Covent Garden. ${ }^{54} \mathrm{O}$ wielkim uznaniu dla mistrza ze Stratfordu świadczy również list Poniatowskiego z 17 lipca 1755 do Charlesa Yorka, w którym pada wyznanie:

Kocham Szekspira i będę utrzymywać przez całe życie, że jest więcej wart zainteresowania w Juliuszu Cezarze niż we wszystkim, co regularność francuska lub płodność grecka kiedykolwiek wytworzyła w rodzaju dramatycznym. ${ }^{55}$

Postać Juliusza Cezara niezwykle interesowała polskiego monarchę i wydaje się, że fascynację rzymskim władcą zawdzięcza właśnie Shakespeare’owi.

Pierwszym po wstąpieniu na tron artystycznym zleceniem Stanisława Augusta był cykl czterech wielkoformatowych historycznych płócien ukazujących cnoty, którymi powinien odznaczać się monarcha. Wtedy zamówił do Zamku Królewskiego, za pośrednictwem swojej mentorki Marie Thérèse Geoffrin, dwa obrazy poświęcone Juliuszowi Cezarowi: Przerażenie Cezara na widok głowy Pompejusza i Cezar przed pomnikiem Aleksandra Wielkiego. Inspiracją dla pierwszego były Żywoty równoległe Plutarcha, zaś dla drugiego - Żywoty Cezarów Swetoniusza. W planach wystroju Sali Wielkiej Przerażeniu Cezara na widok głowy Pompejusza towarzyszyć miała sentencja „Inimici necem trupe patratam exhorruit Caesar" (Zbrodnia wroga popełniona haniebnie przeraziła Cezara) i obraz ten był pomyślany jako ilustracja idei Wielkoduszności. Cezar przed pomnikiem Aleksandra Wielkiego został wybrany, aby ilustrować idee Współzawodnictwa. Obok tych dwóch dzieł zawisły płótna: Scilurus, król Scytów, na łożu śmierci nakazuje dzieciom zgodę będący alegorią Zgody oraz Wstrzemięźliwość Scypiona ilustrujący Sprawiedliwość. ${ }^{56}$

$52 \quad$ Ibidem, s. 19.

53 „Katalog książek znajdujących się w Pałacu Królewskim w Łazienkach”, AGAD, Arch. Ks. J. Poniatowskiego, rkps 270, s. 10-11.

54 J. Komorowski, op. cit., s. 27-29.

55 Stanisław August Poniatowski do Charlesa Yorke'a, Petersburg 17 XII 1755, BL Add. 35634, k. 292; cyt. za: R. Butterwick, Stanisław August a kultura angielska, przekł. M. Ugniewski, Warszawa 2000, s. 93.

56 A. Badach, Inicjatywy artystyczne z pierwszych lat panowania Stanistawa Augusta - ewolucja form i treści, [w:] Stanisław August ostatni król Polski, red. A. Sołtys, Warszawa 2011, s. 75-79. 


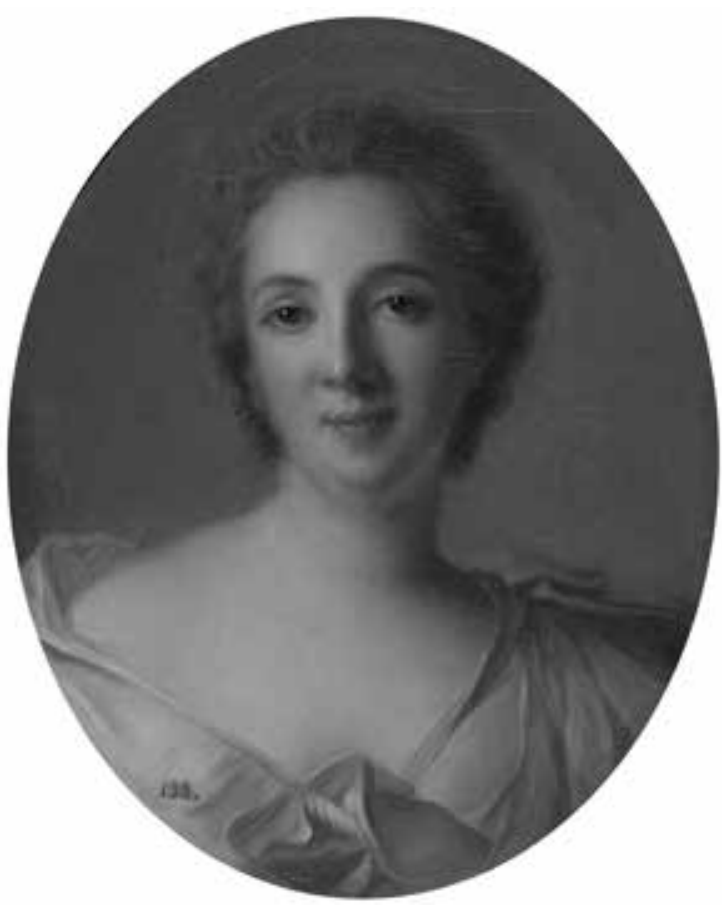

Portret Marie Thérèse Geoffrin wg Jeana Marca Nattiera, po 1738, Muzeum Łazienki Królewskie. Fot. A. Kotlarski

Kolejny wizerunek Juliusza Cezara na zamówienie króla, tym razem rzeźbiarski, został wykonany w latach 1785-1786 przez Angela Puccinellego. Posąg, wraz z trzema innymi: Scypiona Afrykańskiego Starszego, Hannibala i Pompejusza, zdobił Salę Tronową. ${ }^{57}$ Wszyscy władcy reprezentowali kardynalne cnoty królewskie: Wstrzemięźliwość, Męstwo, Sprawiedliwość i Mądrość. Wybór postaci nie był przypadkowy, ponieważ budziły one w XVIII wieku refleksje nad dziejami republikańskiego Rzymu.

Źródłem królewskich fascynacji Juliuszem Cezarem były również Żywoty równoległe Plutarcha, a także Dialogues des morts Françoisa Fénelona, popularne we Francji w pierwszej połowie XVIII wieku i thumaczone fragmentarycznie na język polski w $1770 .{ }^{58} \mathrm{~W}$ dziełach tych podkreślono takie wartości jak heroizm, patriotyzm, wspaniałomyślność, prostota i mądrość.

Przy omawianiu reprezentacji władzy w dramacie Shakespeare'a i postaci samego dramatopisarza warto jeszcze zwrócić uwagę na obraz, który monarcha otrzymał w prezencie od swojego brata, prymasa Michała Poniatowskiego w 1792. Dzieło Jacoba Christopha Le Blona i jego warsztatu odnotowane było

57 A. Rottermud, Zamek Warszawski w epoce oświecenia, Warszawa 1989, s. 159.

58 Ibidem, s. 161-162. 
w „katalogach królewskiej galerii i dotychczasowej literaturze [jako] wizerunek Williama Szekspira". ${ }^{99}$ Ten zachowany do dzisiaj portret można oglądać w Galerii Obrazów w Pałacu na Wyspie, w rzeczywistości ukazuje on jednak nie dramatopisarza, lecz angielskiego poetę epoki elżbietańskiej, Edmunda Spencera. ${ }^{60}$

Na wybór Shakespeare'a jako jednego z najznakomitszych dramatopisarzy na plafonie nowo otwartego teatru złożyły się młodzieńcze doświadczenia estetyczno-teatralne Poniatowskiego oraz fascynacja jego umiejętnością oddania „kolorytu przedstawionych miejsc i czasów" ${ }^{61}$ Stanisław August interesował się również językiem angielskim. William Cox napisał w relacji z podróży, że

Jego Królewska Mość mówił dotąd po francusku, lecz teraz uczynił mi zaszczyt konwersując ze mną po angielsku, w którym to języku mówi nadzwyczaj dobrze. [...] Zna dobrze naszych najlepszych autorów, a jego entuzjastyczny podziw dla Szekspira dał mi najbardziej przekonujący dowód jego bliskiej znajomości naszego języka i upodobanie do piękna prawdziwej poezji. ${ }^{62}$

Wydaje się, że król, umieszczając profil Shakespeare'a na teatralnym plafonie, pragnął podkreślić swoje zainteresowanie nie tylko kulturą i sztuką angielską, ale również systemem ustrojowym. Polski monarcha uważał być może, że Elżbieta I, królowa Anglii, w sposób doskonały wypełniała monarsze powinności wobec swojego narodu, umiejętnie prowadziła politykę i unikała starć $\mathrm{z}$ innymi krajami. ${ }^{63}$

\section{RACINE I MOLIÈRE}

Kolejnym dramatopisarzem ukazanym przez Plerscha na plafonie w Teatrze Królewskim jest Jean Racine. W XVIII wieku był uważany za najwybitniejszego, obok Corneille'a, francuskiego tragediopisarza siedemnastowiecznego klasycyzmu. Na twórczość Racine'a wpływ mieli pisarze starożytni, on sam powoływał się wielokrotnie na autorytet Eurypidesa, Seneki czy Plutarcha, a w centrum jego zainteresowania była Poetyka Arystotelesa. ${ }^{64}$ Zgodnie z Arystotelesowską koncepcją dramatu pokazywał siłę namiętności swoich bohaterów, którzy zarówno przerażają, jak i budzą litość. ${ }^{65}$

59 D. Juszczak, H. Małachowicz, Galeria obrazów Stanisława Augusta w Łazienkach Królewskich: katalog, Warszawa 2015, s. 229.

60 Ibidem, s. 231.

$61 \quad$ P. Kencki, Czterej dramatopisarze w Teatrze Królewskim w Starej Oranżerii, op. cit., s. 2.

62 Cyt. za: R. Butterwick, op. cit., s. 93.

63 A. Rottermund, op. cit., s. 149; R. Butterwick, op. cit., s. 40: „Zarówno angielscy katolicy, w szczególności jezuici, jak protestanccy sekciarze znajdowali w Rzeczypospolitej raj. [...] polscy katolicy potępiali Elżbietę I jako „papieżycę”, której ręce były splamione krwią niewinnych katolików, a protestanci czynili z niej bożyszcze”.

64 B. Sosień, Wstęp, [w:] J. B. Racine, Andromacha, Berenika, Fedra, przekł. M. Wroncka, K. Brończyk, A. Międzyrzecki, Wrocław 1997, s. VII.

65 Ibidem, s. L-LI. 
Publiczność teatru dworskiego w Łazienkach doskonale znała i ceniła dramaty Racine'a. Jego pierwszą sztuką graną w Polsce była Andromacha, którą wystawiono w 1675 w Jaworowie z okazji imienin króla Jana III Sobieskiego, z inicjatywy królowej Marysieńki. Dramat zagrano w oryginale, aktorami byli Francuzi i Francuzki. Uroczystości towarzyszył również balet i popisy akrobatyczne, a dekoracje, kostiumy i rekwizyty zdobiły koronne klejnoty. ${ }^{66}$

O dramacie wystawionym dla Jana III warto wspomnieć z tej przyczyny, że Stanisław August posługiwał się figurą Sobieskiego jako symbolu władcy-wojownika ${ }^{67}$, a w swojej kolekcji gromadził dzieła sztuki ukazujące zwycięzcę walk pod Wiedniem i Parkanami. Z okazji inauguracji pomnika Jana III w Łazienkach król zorganizował 14 września 1788 widowisko dla ludzi wszystkich stanów, zaplanowane jako narodowe święto. ${ }^{68}$

W czasach Stanisława Augusta głównym propagatorem dzieł Racine'a był Stanisław Konarski. Wprowadził jego dramaty na scenę pijarskiego konwiktu Collegium Nobilium. Uczniowie zakonu wystawili m.in. Atalię, komedię Pieniacze i Ifigenię. Obok Racine'a prezentowano również dzieła Molière'a, Corneille'a i Voltaire'a. ${ }^{69}$ Ifigenię wystawiono w 1764 w pałacu Marii Radziwiłłowej w Warszawie, zagrano ją prawdopodobnie po francusku, natomiast Fedrę, którą przełożył na polski Wojciech Turski w 1787, wystawiono w pałacu Karoliny księżnej de Nassau. Adam Kazimierz Czartoryski również wyrażał fascynację Racinem, w szczególności cenił Andromachę, Brytannika, Ifigenię, Fedrę i Atalię.

Obok portretu Racine'a ukazano na plafonie Molière'a, którego nazwisko zapisano w wersji spolszczonej. Jego sztuki bardzo często wystawiano w teatrach w XVIII wieku. Molière'a uwielbiali rewolucjoniści we Francji, w czerwcu 1791 powstał w Paryżu rewolucyjny teatr, który przyjął nazwę La Maison de Molière. ${ }^{70}$

W czasach stanisławowskich chętnie dokonywano spolszczenia komedii Molière'a. Sięgali po nie m.in. Franciszek Zabłocki, Wojciech Bogusławski i Franciszek Bohomolec. Warto też przypomnieć premierę Natrętów Józefa Bielawskiego, dla których inspiracją była sztuka Molière'a Les Fâcheux. ${ }^{71}$ Przed-

\footnotetext{
66 Ibidem, s. LXXXI.
}

67 Niebawem w Muzeum Łazienki Królewskie ukaże się edycja źródłowa tekstów publicystycznych Stanisława Augusta, wśród nich Suum cuique (oprac. P. Skowroński), w którym Stanisław August wyrażał się ambiwalentnie o Janie III: ,Jan Sobieski wielkie miał talenta z wielkimi zmieszane defektami. Wielkie są czyny jego, byłyby większe, gdyby nieprzystojna chciwość w ciasnym prywatnych zysków okręgu nie była myśli ścisnęła jego. Co przyłączone do zbytecznej dla królowej powolności, osłabiło ku niemu ufność i poważanie kraju, nad którym panował".

68 I. Kadulska, Uroki widowiska pod obłokiem dla różnego stanu ludzi (niedziela 14 września 1788 r. w Eazienkach), [w]: Przyjemność w kulturze epoki rozumu, op. cit., s. 244.

69 B. Sosień, op. cit., s. LXXXII.

70 M. Dębowski, op. cit., s. 144.

71 P. Kencki, Molière i inni, „Pamiętnik Teatralny” 2014 z. 4, s. 11-12. 
stawienie to zapoczątkowało działalność Teatru Narodowego subwencjonowanego przez Stanisława Augusta. Komedię po raz pierwszy wystawiono 17 sierpnia $1661 \mathrm{w}$ ogrodach w Vaux-le-Vicomte, należących do superintendenta finansów Ludwika XIV, Nicolasa Fouqueta. Wśród zaproszonych gości był również Król-Słońce. Imponującego widowiska pozazdrościł Fouquetowi młody monarcha i polecił go dożywotnio uwięzić. Kilka lat później Vaux-le-Vicomte przyćmił pałac wersalski. ${ }^{72}$

Molière na inauguracji teatru dworskiego Stanisława Augusta gościł zarówno na plafonie, jak i na scenie, reprezentowany przez komedię George Dandin. ${ }^{73}$

Wiek XVIII to czas wyjątkowego zainteresowania francuskimi dramatopisarzami, dlatego też przedstawienie w gronie czterech dramatopisarzy Racine'a i Molière'a było oczywiste. Umieszczenie tych właśnie wizerunków to efekt świadomej polityki Stanisława Augusta. Król i jego stronnictwo pragnęli, aby ci właśnie Francuzi stanowili nośnik pożądanej, zachodniej cywilizacji.

Zarówno Racine'a, jak i Molière'a chętnie wystawiano w Polsce. Ich dzieła grano w oryginale i po polsku i miały one wpływ na kształt kultury oświeceniowej w Polsce. ${ }^{74}$

\section{KURTYNA}

Zanim na scenie teatru dworskiego pojawiło się dystyngowane towarzystwo, odgrywające dwie komedie i balet, publiczność zgromadzona w Teatrze Królewskim podziwiać mogła malowidło na kurtynie, niewątpliwie potęgujące napięcie.

Autorem kurtyny był również Plersch. Złocona kurtyna jego autorstwa przedstawiała dziewięć muz na Parnasie. Do dzisiaj zachowały się w zbiorach Narodowego Zakładu im. Ossolińskich dwa rysunki - projekty kurtyn przypominające malarstwo Françoisa Bouchera, Jeana Honoré Fragonarda i Antoine'a Watteau. Rysunki te, różniące się nieznacznie w szczegółach, są prawdopodobnie szkicami kurtyn do królewskiego teatru w Starej Oranżerii. ${ }^{75}$

$\mathrm{Na}$ zasłonie teatralnej, podobnie jak na plafonie, król został pokazany jako Apollo, a widniejący z prawej strony kompozycji Pałac na Wyspie symbolizował Parnas, czyli siedzibę muz. Kurtyna stanowiła odniesienie do sceny ukazanej na plafonie i sugerowała widzom, aby odczytywali Łazienki jako siedzibę Stanisława Augusta - mecenasa, pod którego rządami rozwija się sztuka na najwyższym poziomie artystycznym.

72 Idem, Od Les Facheux do Natrętów, „Pamiętnik Teatralny” 2015 z. 3-4, s. 7.

73 Idem, Molière i inni, op. cit., s. 10.

74 Z. Rejman, Rozkosze negacji. Inny i obcy w kulturze polskiego oświecenia, [w:] Przyjemność w kulturze epoki rozumu, op. cit., s. 275.

75 B. Król, Działalność teatralna Jana Bogumiła Plerscha, „Pamiętnik Teatralny” 1954 z. 3-4. 
Nad kurtyną namalowano pięciopolowy herb Rzeczypospolitej z umieszczonym w polu sercowym herbem Poniatowskich - Ciołkiem. Herb wykonany $\mathrm{w}$ technice en grisaille jest podtrzymywany przez dmące w trąby Sławy. To przedstawienie stanowiło dla osiemnastowiecznej arystokracji czytelny znak obecności władcy, którego chwała jest głoszona przez personifikację Sławy. Król wykorzystał w sali widowiskowej herb ze względu na jego wielowiekową tradycję reprezentacji władzy i jako konserwatywny znak przydający autorytetu panującemu. ${ }^{76}$

\section{LA PARTIE DE CHASSE DE HENRI IV}

Po rozsunięciu kurtyny rozpoczęto spektakl, prezentując komedię La partie de chasse de Henri IV (Łowy Henryka IV) Charles'a Collé. Ten wybór nie mógł być zaskoczeniem, postać króla francuskiego - Henryka IV była bardzo popularna w epoce oświecenia za sprawą Voltaire'a, autora słynnej Henriady. Także sztuka Collé była dobrze znana w XVIII wieku. Grano ją już wcześniej dla Stanisława Augusta, 6 września 1766, w rocznicę koronacji, wtedy również po francusku. ${ }^{77}$

Collé skomponował komedię w 1760 i nadał jej tytuł Le Roi et le Mounier (Król i młynarz). Inspiracją była jednoaktówka Dodsleya The King and the Miller. Dwukrotnie, w 1762 i 1764, Collé poprawiał dramat, nadając ostatecznej wersji tytuł La partie de chasse de Henri IV.

Fabuła utworu jest prosta. Henryk IV polował w lesie wraz ze swymi dworzanami. Gdy zapadł wieczór, oddalił się od swych towarzyszy i został schwytany przez chłopa, który uważał go za kłusownika. Król ukrył swoją tożsamość, udając, iż jest oficerem niskiej rangi. Chłop zaprosił go do domu i przyjął gościnnie. Prawdziwa tożsamość Henryka IV została ujawniona dopiero wtedy, gdy został odnaleziony przez swoich dworzan. Król przed odejściem podarował bogaty posag dwóm parom, które wkrótce miały się pobrać. ${ }^{78}$

Fabuła komedii pokazuje Henryka IV jako dobrego i sprawiedliwego władcę, z którym miał być utożsamiany Stanisław August. Arystokracja, oglądając komedię, miała przywoływać w myślach czyny wielkiego Francuza, którego wychwalał Voltaire, i przenosić to wyobrażenie na polskiego monarchę. Warto tu przytoczyć Henriadę. Oto fragment pierwszej pieśni:

Opowiem o bohaterze, co Francją władał,

Co tron prawem zwycięstwa i rodu posiadał,

76 M. Górska, Symbolika panowania Stanisława Augusta - herb Ciołek, insygnia, dewizy, [w:] Stanisław August i jego Rzeczypospolita. Dramat państwa, odrodzenie narodu, red. A. Sołtys, Z. Zielińska, Warszawa 2013, s. 33-34.

77 J. Pawłowiczowa, Teatr i krytyka, [w:] Teatr Narodowy 1765-1794, op. cit., s. 149.

78 C. D. Brenner, Henri IV on the French Stage in the Eighteenth Century, "PMLA" 1931, vol. 46, nr 2, s. 543. 


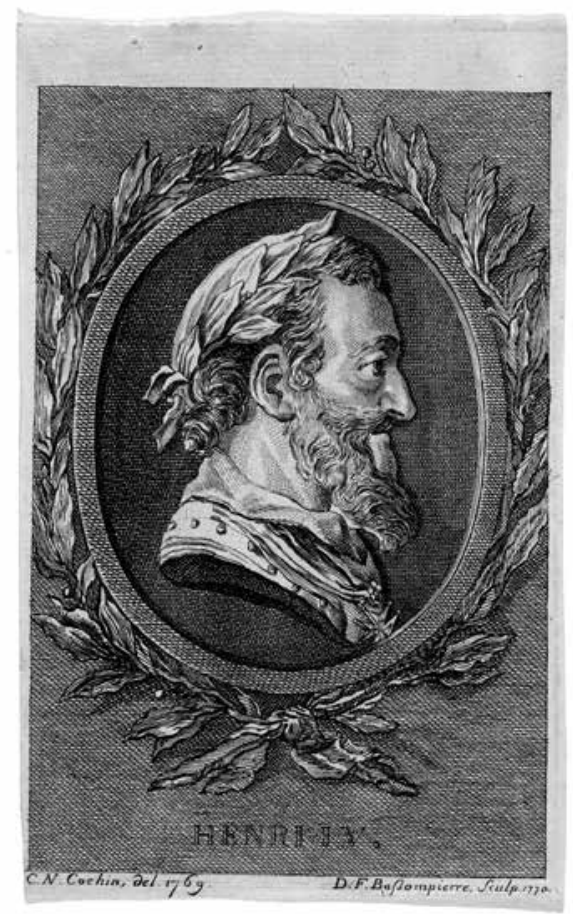

Portret Henryka IV, ryt. D. F. Bassompierre wg Charles'a Nicolasa Cochina syna, 1770, Zamek Królewski w Warszawie. Fot. A. Ring, L. Sandzewicz

Co, długim pasmem nieszczęść nauczon królować,

Umiał przydusić spiski, zwyciężyć, darować,

Majencyjusza, Ligę, Hiszpanów ukrócić,

I podbiwszy Francuzów, szczęście im przywrócić. ${ }^{79}$

W kontekście fascynacji Stanisława Augusta postacią Henryka IV trzeba przywołać również fragment siódmej pieśni, w której święty Ludwik objawia Henrykowi IV istotę nieba i piekła ${ }^{80}$, i tak się do niego zwraca:

Wtenczas Ludwik, z głowy swej zdejmując koronę,

Włożył ją na Henryka czoło niezwalczone.

Panuj, rzekł mu, zwyciężaj i bądź sprawiedliwym,

Podporą mego rodu, synem mym prawdziwym.

Ale tron, o Burbonie! Jest dla ciebie mało,

I o więcej ci nieba prosić się zostało. ${ }^{81}$

$79 \quad$ Henriada w dziesięciu pieśniach pana de Voltaire, przekł. E. Słowacki, Warszawa 1803, s. 5.

80 Ibidem, s. 100.

$81 \quad$ Ibidem, s. 101. 
Dzieło Voltaire'a napisane na część Henryka IV Burbona, który sprawował władzę przez dwadzieścia lat, podczas sporów religijnych między hugenotami i katolikami, zostało zadedykowane pamięci królowej angielskiej Elżbiety I. August był pełen uznania zarówno dla królowej, jak i dla Voltaire’a, którego uważał za „chlubę wieku” Oświecenia. W swojej kolekcji zgromadził trzy popiersia i jedną rzeźbę ukazujące postać filozofa. Bardzo dbał również o to, aby być na bieżąco ze wszystkim, co wydawał i nad czym pracował filozof.

Oprócz Voltaire'a również Fénelon podkreślał zdolności Henryka IV w utrzymaniu pokoju między katolikami i kalwinami oraz polityczny ład pod jego panowaniem. Stanisław August, pozostający pod wpływem kultury francuskiej, uważał Henryka IV za władcę idealnego, posiadającego najwznioślejsze cnoty królewskie. W Zamku Królewskim chętnie otaczał się jego wizerunkami. W Pokoju Audiencjonalnym Starym, usytuowanym w obrębie Apartamentu Królewskiego, popiersie Henryka IV znajdowało się obok wizerunków carycy Rosji Katarzyny II, królowej Anglii - Elżbiety I i króla Jana III. Rzeźby ustawiono na stołach konsolowych parami; obok tronu umieszczono popiersia Katarzyny II i Jana III, a naprzeciwko, na tle okien - Elżbiety I i Henryka IV. W swoich zbiorach monarcha miał również niewielki portret Henryka IV, cykl grafik z obrazów Rubensa ukazujących sceny z życia francuskiego władcy. Sam również pozował w kostiumie Henryka IV. ${ }^{82}$

Około 1789 Marcello Bacciarelli namalował portret zatytułowany Stanisław August w kapeluszu z piórami. Obraz ten ukazuje króla w wysokim popiersiu, w czerwonym płaszczu królewskim i kapeluszu z piórami, który określano jako „,chapeau à la Henri IV". Jest nawiązaniem do mitu tego wielkiego władcy-wojownika:

Jest to jedyny malarski wizerunek prezentujący Stanisława Augusta w tzw. „,czapce po koronacji”. W całopostaciowym Portrecie koronacyjnym namalowanym przez Bacciarellego około 17671768 kapelusz w ogóle nie został przedstawiony [...] historyzujący strój, w jakim Stanisław August wystąpił podczas koronacji [...] nawiązywał do postaci wielbionego przez monarchę Henryka IV ${ }^{83}$

Po abdykacji Stanisław August pozował Élisabeth Vigée-Lebrun w kostiumie Henryka IV. Nie wiemy jednak, kto był pomysłodawcą tej stylizacji. Być może królewska siostrzenica Urszula z Zamoyskich Mniszchowa, która w korespondencji z matką Ludwiką Poniatowską porównywała króla do francuskiego władcy, a może sam Stanisław August. W portrecie tym po raz ostatni monarcha buduje swój wizerunek, stojąc w ,sprzeczności z faktycznymi dokonaniami, w tragicznym momencie upadku Rzeczypospolitej, której koronę dwa lata wcześniej zmuszony był oddać" ${ }^{84}$

82 A. Rottermud, op. cit., s. 148-149. Zob. T. Mańkowski, Galeria Stanisława Augusta, Lwów 1932, s. 223, poz. 142 .

83 D. Juszczak, Marcello Bacciarelli. Najpiękniejsze portrety, Warszawa 2018, s. 176.

84 Eadem, Ikonografia Stanisława Augusta. Portrety, [w]: Stanisław August ostatni król Polski, op. cit., s. 151. 


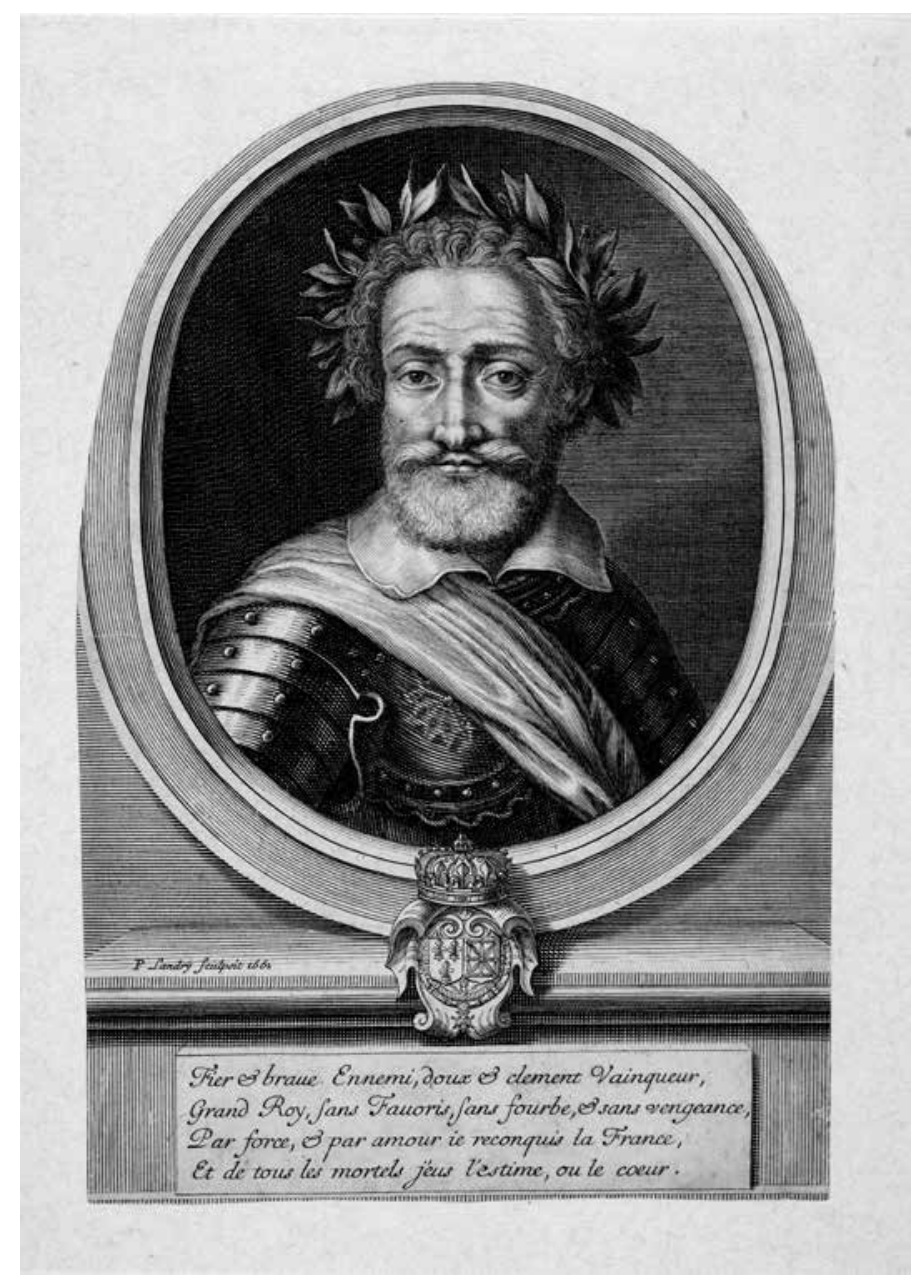

Portret Henryka IV, ryt. Pierre Landry wg Jacoba Bunela, 1662, Zamek Królewski w Warszawie. Fot. A. Ring, L. Sandzewicz

Wydaje się, że pierwszą osobą, która porównała polskiego monarchę do Henryka IV była Marie Thérèse Geoffrin, prowadząca w Paryżu słynny salon filozoficzny przy 372 rue Saint-Honoré. W grudniu 1764 sześćdziesięciopięcioletnia „królowa z ulicy świętego Honoriusza” napisała do polskiego króla:

Bo, doprawdy, Drogi Panie, widzę w Panu jednego ze wspanialszych królów Europy, a przynajmniej posiada Pan w szczególnym stopniu wszystko to, co jest potrzebne, by nim zostać; umysł bystry, cnót wiele, rozległe wiadomości. Przy tym byłeś zwykłym człowiekiem, co daje wiele korzyści w poznaniu ludzi i spraw. Królowie zrodzeni na tronie znają jedynie ludzi, wśród których żyją: o wszystkim dowiadują się przez tychże ludzi, którzy ukazują im tyle, ile wymaga ich własny 
interes. Będziesz, Drogi Synu, polskim Henrykiem IV. Masz dużo do zrobienia, ale jesteś młody; gdy ma się wiele czasu przed sobą, można znaleźć odwagę do czynu. ${ }^{85}$

Fascynacje Francją i zachwyt nad królem francuskim tłumaczy wystawienie komedii Charles'a Collé w nowo otwartym teatrze. Henryk IV miał stanowić odniesienie do Stanisława Augusta, dobrego i sprawiedliwego władcy. Nie wiemy, w jakim kostiumie występował aktor, grający francuskiego króla. Jest prawdopodobne, że był ubrany, tak jak król na petersburskim portrecie Vigée-Lebrun, który być może był dla Stanisława Augusta pięknym wspomnieniem otwarcia teatru. ${ }^{86}$

Komedia Collé, chociaż opowiadająca o królu Francji, miała reprezentować kulturę dworu Stanisława Augusta, jej wystawienie wiązało się z chęcią ustanowienia i wzmocnienia królewskiej władzy, miało pokazać wartości jego dworu. Fabuła dramatu rozgrywała się w dwóch porządkach: będąc wierną oryginałowi, jednocześnie opowiadała o cnotach polskiego króla.

\section{GEORGE DANDIN}

Po La partie de chasse de Henri IV odegrano sztukę George Dandin, której prapremiera odbyła się 15 lipca $1668 \mathrm{w}$ wersalskim parku. Widowisko zorganizowano z okazji pokoju zawartego w Akwizgranie, kończącego wojnę z Flandrią. Komedię ukazującą męża wystrychniętego na dudka przez niewierną i sprytną żonę wystawiono $\mathrm{w}$ ramach fety złożonej, na którą składały się liczne rozrywki, takie jak balety czy fajerwerki. ${ }^{87}$

Sztuka napisana przez Molière'a łączy farsę i komedię obyczajową. Motyw przebiegłej kobiety i rogacza przejął dramatopisarz między innymi od Boccaccia. Wzbogacił go o współczesne sobie realia ${ }^{88}$ Ukazane w sztuce osoby, pochodzące z różnych stanów społecznych, to postaci, które nie wzbudzają sympatii, sztuka jest również pozbawiona szczęśliwego zakończenia. Komedia została w XVIII wieku przełożona na język polski. Wydał ją Piotr Dufour w 1779 pod tytułem Mąż zawstydzony, a w 1780 - Mąż oszukany. Drugą wersję grano w latach 1780, 1781 i $1788 .{ }^{89}$

Z okazji inauguracji Teatru Królewskiego sztukę Molière'a wystawiono w oryginale. Ten wybór potwierdził popularność francuskiego dramatopisarza i pokazał aspiracje dworu, jego chęć dorównania dworowi francuskiemu.

85 Cyt. za: I. Zatorska, Marie-Thérèse Geoffrin - guwernantka Stanisława Augusta, [w:] Stanistaw August i jego Rzeczpospolita, op. cit., s. 135.

86 B. Król-Kaczorowska, Budynki teatrów, dekoracje i kostiumy, [w:] Teatr Narodowy 17651794 , op. cit., s. 891.

87 J. Lukaszewicz, George Dandin, ou le mari confondu w polskim oświeceniu. Wersja mieszczańska i chłopska, „Pamiętnik Teatralny” 2014 z. 4, s. 95.

88 Ibidem, s. 96.

89 Ibidem, s. 81-82. 


\section{RYBAKI}

Po komedii George Dandin odegrano balet Rybaki w choreografii Daniela Curza. Na deskach teatru dworskiego wystąpił zespół tancerzy Jego Królewskiej Mości powołany z młodzieży wykształconej w szkole artystycznej Antoniego Tyzenhauza. Wyboru tancerzy i tancerek dokonał Françoise Le Doux ${ }^{90}$, zatrudniony przez Tyzenhauza, spośród „dzieci i młodzieży poddańczej pochodzącej z litewskich dóbr podskarbiego". ${ }^{91}$ Po śmierci Tyzenhauza Le Doux wraz z młodzieżą baletową został przyjęty do służby królewskiej. Dzięki niemu upowszechniono w Polsce zasady nauczania tańca klasycznego opracowane we Francji w XVIII wieku. Oprócz Le Doux zatrudniono również Wenecjanina - Daniela Curza, który otrzymał stanowisko maître de balet. ${ }^{92}$

Królewski zespół baletowy prezentował wysoki poziom umiejętności, był pierwszym narodowym zespołem na polskim dworze po prawie stu latach prymatu artystów francuskich, włoskich i niemieckich. ${ }^{93} \mathrm{~W}$ osiemnastowiecznych dokumentach i na afiszach tancerzy narodowych określano jako „Tancerzy Jego Królewskiej Mości”, „Balet J.K.Mci”, „Baletników J.K.Mości”, „Tancerzy Nadworni Najjaśniejszego Pana”, „Ballet du Roy” oraz „Baletników Królewskich”. 94 Ten zespół rozpoczął historię zawodowego baletu polskiego. Tancerze z powodzeniem występowali w rolach tanecznych, pantomimicznych i aktorskich ${ }^{95} \mathrm{~W}$ relacjach ze spektakli podkreślano stylistyczną jednorodność baletników. ${ }^{96}$

Posiadanie królewskiego zespołu baletowego było pożądane przez monarchów. Balet cieszył się popularnością od czasów Ludwika XIII do Ludwika XVI. O tańcu klasycznym wypowiadali się osiemnastowieczni myśliciele, Diderot, d'Alambert i Rousseau ostrze krytyki kierowali w stronę nienaturalności baletu, tańca w maskach, perukach i ogromnych rozmiarów kostiumach. Zapoczątkowało to zmianę w estetyce baletu, która wiąże się z nazwiskiem Jeana Georgesa Noverre'a. Jego Listy o tańcu spowodowały ogromne zainteresowanie tą sztuką i debatę o niej. Listy były rodzajem manifestu, Noverre wyrażał w nich pragnienie, aby balet oddawał myśli i namiętności, tak jak to robią poezja, malarstwo i rzeźba. Stanisław August nawet otrzymał w 1766 od Noverre'a, za pośrednictwem Augusta Moszyńskiego, jego jedenastotomowe dzieło dotyczące teorii i praktyki tańca, muzyki, kostiumów i dekoracji. Ten zachowany do dzisiaj wspaniały rękopis został ozdobnie wykaligrafowany i oprawiony w czerwony safian, ze złotymi narożnikami i brzegami. Baletmistrz proponował królowi również wystawienie

\footnotetext{
90 Zob. W. Zawadzki, Teatr we wspomnieniach i listach, [w:] Teatr Narodowy 1765-1794, op. cit.

91 A. Żórawska-Witkowska, op. cit., s. 190.

92 B. Mamontowicz-Łojek, Tancerze króla Stanistawa Augusta 1774-1798, Warszawa 2005, s. 90-91.

93 A. Żórawska-Witkowska, op. cit., s. 190.

94 B. Mamontowicz-Łojek, op. cit., s. 91.

95 Ibidem, s. 148.

96 A. Żórawska-Witkowska, op. cit., s. 196.
} 
w jego obecności baletów i poświęcenie mu swojego talentu. Monarcha jednak nie zaprosił baletmistrza do Warszawy. ${ }^{97}$

Wydaje się, że spektakl Rybaki wystawiono w nowej estetyce Noverre'a, ponieważ Curz zetknął się z wielkim reformatorem tańca klasycznego i jego „baletami z akcjąa"98, sam też wielokrotnie realizował takie balety. Jak donosiła ówczesna prasa, balet Rybaki wykonany przez zespół narodowy został ,z powszechnym oklaskiem dopełniony". ${ }^{99}$ Także później cieszył się uznaniem. W liście majora Franciszka Ryxa do Franciszka Ryxa starosty z 1796 czytamy: „Ostatniej niedzieli w czasie baletu Rybaki oficer rosyjski rzucił George’owi [Walińskiemu] sakiewkę z zawartością 3 dukatów, on przyrzekł podzielić się z tancerzami”. ${ }^{100}$

Balet Rybaki był jednym z najbardziej lubianych przez publiczność i najczęściej wystawianych. Obok niego podobną popularnością cieszyły się: Kora i Alonzo, Niechęć miłosna, Małzeństwo Samnitów, Tańce kozackie i węierskie, Henryk II, Kapitan Sander i Kleopatra. Król wielokrotnie wykorzystywał balet do propagowania swoich idei politycznych. Niemałe znaczenie miały występy zespołu składającego się wyłącznie z polskich artystów dla wzbogacenia i utrzymania przedstawień narodowych. ${ }^{101}$

$* * *$

Świętowanie inauguracji Teatru Królewskiego w dniu 6 września 1788 było tak zainscenizowane, aby dać majestatowi królewskiemu należytą oprawę ceremonialną, ustanowić i wzmocnić jego władzę, a także otoczyć go symbolami. Imponujące widowisko oparto na solidnych podstawach: antycznych - greckich i rzymskich (przedstawienia na plafonie i kurtynie), francuskich (w repertuarze były dwie komedie francuskich dramatopisarzy) oraz polskich (wystąpił balet narodowy).

Wybór repertuaru na inaugurację był podyktowany zasadą przyjemności, która zajmowała ważne miejsce we francuskiej moralistyce tamtego czasu. Teatr dworski Stanisława Augusta, nie ukrywając aspiracji do francuskiej kultury, wyrażał moralne przyzwolenie dla zbytku czy rozrywki ${ }^{102}$, przyjmując formułę théâtre de société.

Relacja $\mathrm{z}$ widowiska napisana przez l'abbé Renaud, jak również utrwalone opisy innych wydarzeń dworskich w Łazienkach, zwracają przede wszystkim uwagę na iluzję obrazu scenicznego, dostarczającą przeżyć estetycznych. Wiek Świateł, w którym z upływem czasu ginęła wiara w racjonalizujący postęp, opierający się na wierze $\mathrm{w}$ istnienie wartości absolutnych, odczuwał potrzebę zjawisk

97 A. Szyfman, Ocalony rękopis i znalezione listy Noverre'a, „Pamiętnik Teatralny” 1954 z. 3-4.

98 B. Mamontowicz-Łojek, op. cit., s. 90.

99 Teatr Narodowy 1765-1794, op. cit., s. 581.

100 Major Franciszek Ryx do starosty Franciszka Ryxa, Warszawa, 6 I 1796,AGAD, Korespondencja Stanisława Augusta, t. 11, k. 20; cyt. za: B. Mamontowicz-Łojek, op. cit., s. 105.

$101 \quad$ Ibidem, s. 149.

102 W. Sajkowski, Przyjemność a konserwatywna moralistyka francuska w bibliotece i programie Collegium Nobilium w Warszawie, [w]: Przyjemność w kulturze epoki rozumu, op. cit., s. 265. 
kompensacyjnych, sztuk w ich estetyzowanej formie ${ }^{103}$, a teatr dworski Stanisława Augusta takich właśnie dostarczał. Otwierał przed widzami pojedynczy, określony świat, wyimaginowany obszar, który oddalał autentyczne życie i służył zabawie. Inauguracja była więc rodzajem „wyrwania kotwicy” $\mathrm{z}$ dotychczasowych związków ze światem. ${ }^{104}$ Efekt tego wyrwania został osiągnięty poprzez technikę zamknięcia teatralnego świata w budynku Starej Oranżerii i umiejętne ukrycie mechanizmów przedstawienia. ${ }^{105}$ Wejście do tego świata powodowało, że przyjmowano szczególną postawę, która nie rozstrzygała w żaden sposób o prawdzie i fałszu. Repertuar z potęgą scenografii, rekwizytów i kostiumów potrafił skłonić do dania wiary wszystkiemu, co zostało pokazane i sprawić, że król i arystokracja odnajdywali siebie w tym wyobrażonym, estetycznym świecie.

Zaproszeni goście byli otoczeni w przestrzeni teatralnej wizerunkami władcy, oglądali zarówno rzeczywiste ciało króla jak i ciała wyobrażone, a w świecie teatru, który jest estetycznym pozorem, wyimaginowane ciała monarchy były traktowane jako przedmiot estetyczny. Widzowie mogli je przeżywać tak, jak się przeżywa dzieło sztuki. Podziwiali monarchę oglądającego spektakl w loży, króla jako Apollina na teatralnym plafonie i kurtynie, a także na scenie, jako Henryka IV Burbona, dobrego i sprawiedliwego władcę. Wielokrotnych przedstawień dopełniał również kartusz herbowy, umieszczony nad kurtyną, w którego sercu polowym został umieszczony Ciołek.

Czterej dramatopisarze: Sofokles, Shakespeare, Racine i Molière ${ }^{106} \mathrm{w}$ medalionach i poniżej iluzjonistyczna widownia „krążyli” wokół postaci króla na plafonie, który stanowił centrum, zwornik dla całej sali widowiskowej. Monarcha był więc zarówno uczestnikiem, jak i obserwatorem widowiska.

Król za pomocą teatralnej iluzji pokazywał siebie przez filtry mitologii i ideologii. Podobnie jak inni monarchowie potrzebował "masek” i wydaje się, że jego ulubioną była „maska antyczna”. Jego wizerunki w różnych mediach dawały arystokracji szansę dostrzeżenia w królu czegoś nieznanego, wydobywały na światło dzienne coś dotąd niewidzialnego. Jednak była to raczej jedynie widzialność powierzchowna, oglądanie ochronnej fasady, która raczej maskowała niż ujawniała prawdziwy obraz monarchy. ${ }^{107}$ Arystokracja, która uczestniczyła w wydarzeniu, musiała schlebiać władcy, ponieważ to on miał błyszczeć i roztaczać blask przepychu. Stanisław August chętnie przyjmował możnych w swojej prywatnej rezydencji, wzorując się na władcy francuskim, Henryku IV. ${ }^{108}$

103 I. Lorenc, Minima aesthetica, op. cit., s. 17.

104 Eadem, Estetyczne uzgodnienie jako temat wspótczesnej fenomenologii francuskiej, [w:] Fenomen i przedstawienie. Francuska estetyka fenomenologiczna, op. cit., s. 55.

105 Eadem, Świadomość i obraz, Warszawa 2001, s. 186-187.

106 R. Butterwick, op. cit., s. 170: „Angielscy krytycy i dramatopisarze, od Drydena do Garricka, widzieli w Szekspirze symbol rosnącej narodowej i imperialnej dumy, ripostę na prestiż Corneilla, Racine'a i Moliera".

107 E. Pontremoli, Nadmiar widzialnego, przekł. M. L. Kalinowski, Gdańsk 2006, s. 114-116.

108 W. S. Magdziarz, op. cit., s. 42. 
W sali widowiskowej miejsce króla znajdowało się w środkowej loży, tak aby król z centralnej pozycji spoglądał na wszystkie widowiska. Również scena, na której wystawiano dramaty, był dostosowana do miejsca, które zajmował panujący. To on, po odsłonięciu kurtyny, delektował się najpełniej teatralnym złudzeniem. Widniejące przed nim zwielokrotnione wizerunki jego osoby symbolizować mogły problemy wynikające ze skończoności istnienia. Przedstawienia były strategią ucieczki przed przemijalnością oraz próbą budowania i ustanawiania swojego autorytetu. ${ }^{109}$ Dzięki nim monarcha uzyskiwał możliwość spojrzenia na siebie z dystansu, usytuowania siebie wobec rzeczy z otoczenia i innych ludzi. Doświadczenie lustra stanowiło doświadczenie Ja jako Innego. Wizerunki mogły powodować więc refleksję nad sobą samym i oddalenie wobec siebie:

Ale jeśli mój obraz kieruje na mnie moje własne spojrzenie, długo mi się przygląda, neutralizuje mnie swą obiektywnością? Powinienem zobaczyć siebie. Powinienem być tamtym. Właśnie ten przymus jest nieznośny. ${ }^{110}$

Stanisław August, obserwując swoje wizerunki, mógł również za Elżbietą I, królową Anglii, powtórzyć słowa, że wystawiony jest na scenie na widoku całego świata i oczy wielu obserwują jego działania. ${ }^{111}$

Powiązanie teatru $z$ władzą znane jest już od antyku, a schemat jego wykorzystania $\mathrm{w}$ propagandzie władzy był wielokrotnie i z powodzeniem powtarzany również na dworze Stanisława Augusta. ${ }^{12}$ Polski monarcha dla osiągnięcia celów społeczno-politycznych potrafił użyć jego perswazyjnej siły i istoty, czyli transformować to, ,co realne, dosłowne, cielesne, obciążone i doczesne - w to, co wyobrażone, artystyczne, lotne, duchowe i transcendentne". ${ }^{113}$ Nośnikiem tej transformacji był przede wszystkim on sam, umiejętnie używający teatralnych efektów dla formułowania tożsamość swojego dworu, a król umiejętnie grający z tożsamością może się pokazywać w różnych rolach i maskach. Sytuację tę wskazał Zbigniew Raszewski pisząc, że

w wielu przedstawieniach - można się dopatrzyć wyrazu propagandy politycznej. Jednak głównym celem było niewątpliwie doprowadzenie widza do ekstazy, przez wytworzenie odpowiedniego nastroju, a także stopniowanie wrażeń: od zaskoczenia do zatarcia granicy między rzeczywistością a fikcją ${ }^{114}$

Celem Stanisława Augusta było wykorzystanie ekstazy i zatarcia granicy między rzeczywistością a fikcją dla ustanowienia nowego obrazu świata. Król powoływał tym samym widowisko sceniczne i pozasceniczne. Jego nowo otwarty teatr łączył czasy, przestrzenie i światy.

109 I. Lorenc, Minima aesthetica, op. cit., s. 43.

110 Ibidem, s. 89-91.

111 S. Orgel, Iluzja władzy. Teatr polityczny w Anglii epoki odrodzenia, przekł. O. Kaczmarek, [w:] Teatr elìbietański, red. A. Chałupnik, Warszawa 2015, s. 256.

112 J. Hernik Spalińska, Sofokles $i$ antyczny teatr grecki, op. cit.

113 K. Braun, op. cit., s. 673.

114 Z. Raszewski, Krótka historia teatru polskiego, Warszawa 1978, s. 31. 